\title{
Occurrence of Spike Disease in Sandal Plantations in Southern Karnataka and Cross Transmission Studies between Sandal Spike and Stachytarpheta phyllody through Dodder (Cuscuta subinclusa)
}

\author{
R. Murali*, K.T. Rangaswamy and H. Nagaraja \\ Department of Plant Pathology, University of Agricultural Science, Bangalore, India \\ *Corresponding author
}

Keywords

Sandal spike,

Phytoplsama,

Stachytarpheta

phyllody, Cross

transmission

Article Info

Accepted:

10 December 2018

Available Online:

10 January 2019

\section{A B S T R A C T}

The sandal spike disease is becoming serious threat to sandal cultivation in the southern states viz., Karnataka, Tamilnadu and Kerala. The high price of Sandal wood declared by the government of Karnataka and liberalization for the private cultivation of Sandal by valid license from the forestry department has encouraged the farmers to go for planting of Sandal on even very fertile soils. A number of Sandal plantations have also come up Karnataka. The disease incidence and prevalence in farmer's sandal plantations was assessed by using complete enumeration method. 24 sandal plantations were surveyed from five districts in Southern Karnataka, the incidence of sandal spike disease. The disease incidence was ranged from 0 to 18 per cent. The maximum incidence of 18 per cent was recorded in Sira taluk of Tumkur district, followed by Shimoga, 1.65 per cent. The least incidence of 0.33 per cent was recorded in plantations of Tygarthi village. However, the plantations of Chickballapur, Chickmagalore and Chitradurga were free from incidence of spike disease. The presence of spike disease was confirmed by PCR technique using phytoplasma specific primers. Cross transmission studies between Sandal spike and Stachytarpheta phyllody through Dodder (Cuscuta subinclusa) revealed that, spike phytoplasma could not be transmitted to any of the inoculated Stachytarpheta plants, indicating the inability of phytoplasma to infect and establish in the host. The PCR analysis of all dodder inoculated Stachytarpheta plants for the spike phytoplasma also gave negative results and there is no inter-relation between Sandal and Stachytarpheta for transmission of Phytoplasama.

\section{Introduction}

Sandal (Santalum album L.) is an economically important, semi root parasite, perennial, evergreen tree species belongs to the family Santalaceae. It is known for its scented wood and fragrance oil. Although the tree grows in several countries, the best heart wood formation takes place only in India. In India, it occupies 8513 square kilometres area in states of Karnataka, Kerala, Madhya Pradesh, Maharashtra, Andra Pradesh and Tamil Nadu. The disease is characterised by witches'-broom symptoms, consisting of small, narrow leaves which turn pale-green or yellow on branches. Affected leaves become 
overcrowded due to internodes shortening and standout stiffly from branches, acquiring a spike-like appearance Leaves and branches dry out and affected plants eventually die-off within a couple of years from the first appearance of symptoms. The average annual production of sandal wood has been drastically declined from 4000 tonnes to 1044 tonnes in 1965 to 1995 (Srinivasan et al., 1992).

Stachytarpheta indica a common weed species found in the Sandal plantations, was also found infected by the phytoplasma with the characteristic symptoms of stunting, reduced leaf size, proliferation of axillary shoots, shortening of internodes and conversion of floral parts into leaf like structure typically appears like witch's broom (Fig. 1 and 2).

Phytoplasmas, causing Sandal spike disease are single celled, wall-less prokaryotes and they are unable to grow on culture media due to its obligate nature of parasitism; they are mainly depends on its vectors for transmission and spread of the disease (Rangaswamy and Griffith, 1941). The important vectors for Phytoplasmas transmission mainly phloem feeding insects like leafhoppers, plant hoppers and psyllids (Nayar and Ananthapadmanaba, 1977) The incidence of Sandal spike disease in southern Indian states has become predominant constraint for successful management of sandal plantations. Even though, the farmers are willing to increase the area under sandal plantations, but, they are vexed about the dreadful disease and unable to manage the disease permanently using chemicals. However, about Sandal spike disease transmission remains a debatable issue. The information available on phytoplasma incidence in sandal farmer's plantations across the growing regions and the mode of transmission is insufficient to draw conclusion on these aspects. The present study was focused to explore the prevalence/incidence of sandal spike disease in farmer's sandal plantations and role of naturally occurring weed across the growing regions were tested for their role in transmission of Phytoplasma especially in southern Karnataka.

\section{Materials and Methods}

A systematic roving survey was conducted to know incidence level of sandal spike disease across the growing regions. The survey was conducted from Sept 2011- June 2012 in different districts of Karnataka state like Chickballpura, Shimoga, Chitradurga, Chickmangalore. The sandal plantations were assessed for the incidence/status of sandal spike disease by the method, complete enumeration as given by Muniyappa et al., (1980). All the trees/plants were carefully observed for typical symptoms of sandal spike disease for assessing the disease status. The per cent disease incidence was calculated using the following formula,

Per cent disease incidence $=$

Total number of infected plants x 100

Total number of plants observed

This method was employed in the farmer's sandal plantations, where, the trees were distributed in the limited area. The total numbers of healthy and diseased sandal trees were counted in the whole plantation and per cent infected trees were calculated.

\section{Cross infectivity studies}

Seeds of Cuscuta subinclusa were germinated in earthern pots already planted with periwinkle and Vadelia seedlings, after establishment, the shoots of the dodder were trained on to diseased sandal plants. Subsequently the growing tip of the dodder was trained to the test plant i.e., 
Stachytarpheta indica and allowed to establish. The inoculated plants were maintained for three months for development typical symptoms of phytoplasmas (Dijkstra and Lee, 1972).

\section{Results and Discussion}

The occurrence and prevalence of sandal spike disease in farmer's sandal plantations across growing regions in Karnataka (Table 1). Among the surveyed 24 sandal plantations, the disease incidence was ranged from 0 to 18 per cent. A maximum incidence of 18 per cent was recorded at the one of the farmer's Sandal plantations at Sira, tumkur district in Karnataka state.

Table.1 Prevalence of Sandal spike disease in southern Karnataka

\begin{tabular}{|c|c|c|c|c|c|c|}
\hline District & $\begin{array}{l}\text { Location of } \\
\text { plantation }\end{array}$ & $\begin{array}{c}\text { Area } \\
\text { under } \\
\text { plantation } \\
\text { (Acre) }\end{array}$ & $\begin{array}{l}\text { Cropping } \\
\text { system }\end{array}$ & $\begin{array}{l}\text { Age of } \\
\text { the } \\
\text { crop }\end{array}$ & $\begin{array}{l}\text { No. of plants } \\
\text { infected/ } \\
\text { Total No. Of } \\
\text { plants }\end{array}$ & $\begin{array}{c}\% \\
\text { Incidence }\end{array}$ \\
\hline Tumkur & Sira & 2 & ICW Mango & 4 & $79 / 439$ & 18.00 \\
\hline \multirow{6}{*}{$\begin{array}{c}\text { Shimoga } \\
\text { (Sagara taluk) }\end{array}$} & Tyagarthi & 5 & Sole crop & 2 & $10 / 2960$ & 0.33 \\
\hline & Adderi & 1 & IWC Arecanut & 0.4 & $4 / 250$ & 1.60 \\
\hline & Thaligere & 2 & ICW Arecanut & 0.6 & $6 / 550$ & 1.09 \\
\hline & Rippenpet & 2 & IWC Arecanut & 0.5 & $0 / 445$ & 0 \\
\hline & Nedaravalli, & 1 & Sole crop & 1 & $0 / 220$ & 0 \\
\hline & Jamburmane & 2 & ICW mango & 0.6 & $4 / 522$ & 0.76 \\
\hline \multirow{4}{*}{$\begin{array}{c}\text { Shimoga } \\
\text { (Therthahalli } \\
\text { taluk) }\end{array}$} & Mandagadde & 5 & ICW Arecanut & 4 & $10 / 2785$ & 0.35 \\
\hline & Singanbidare & 1 & Sole crop & 3 & $0 / 230$ & 0 \\
\hline & Therthahalli & 2 & ICW Arecanut & 3 & $0 / 480$ & 0 \\
\hline & Kuruvalli & 2 & ICW Arecanut & 0.5 & $0 / 406$ & 0 \\
\hline \multirow{4}{*}{ Chitradurga } & B G kere & 80 & $\begin{array}{l}\text { ICW Coconut } \\
\text { Tamarind }\end{array}$ & $2-14$ & $0 / 18900$ & 0 \\
\hline & Gollahalli & 5 & ICW Mango & 6 & $0 / 2154$ & 0 \\
\hline & Hanagal & 15 & ICW Mango & 5 & $0 / 6250$ & 0 \\
\hline & Kodihalli & 5 & $\begin{array}{l}\text { ICW Mango, } \\
\text { coconut }\end{array}$ & 5 & $0 / 2210$ & 0 \\
\hline \multirow{4}{*}{ Chickballapura } & Bevinahalli, & 6 & $\begin{array}{l}\text { ICW Mango, } \\
\text { Sapota }\end{array}$ & 4 & $0 / 2900$ & 0 \\
\hline & Thondebavi, & 4 & $\begin{array}{l}\text { ICW Mango, } \\
\text { Sapota }\end{array}$ & 1 & $0 / 1715$ & 0 \\
\hline & Muddenahalli & 4 & $\begin{array}{c}\text { ICW Mango, } \\
\text { Gauva }\end{array}$ & 2 & $0 / 1840$ & 0 \\
\hline & Gowribidanuru & 5 & ICW Sapota & 2 & $0 / 2425$ & 0 \\
\hline \multirow{4}{*}{ Chickmagalore } & Kemmannugundi & 6 & ICW Teak, Oak & 4 & $0 / 2545$ & 0 \\
\hline & Kodi camp & 4 & ICW Coconut & 1 & $0 / 1625$ & 0 \\
\hline & Tharikere & 4 & ICW Arecanut & 2 & $0 / 1648$ & 0 \\
\hline & Chickmangalore & 5 & ICW Arecanut & 2 & $0 / 2215$ & 0 \\
\hline
\end{tabular}


Fig.1 Leaves from spike infected tree (B) with reduced leaf size in comparison with healthy leaves (A)

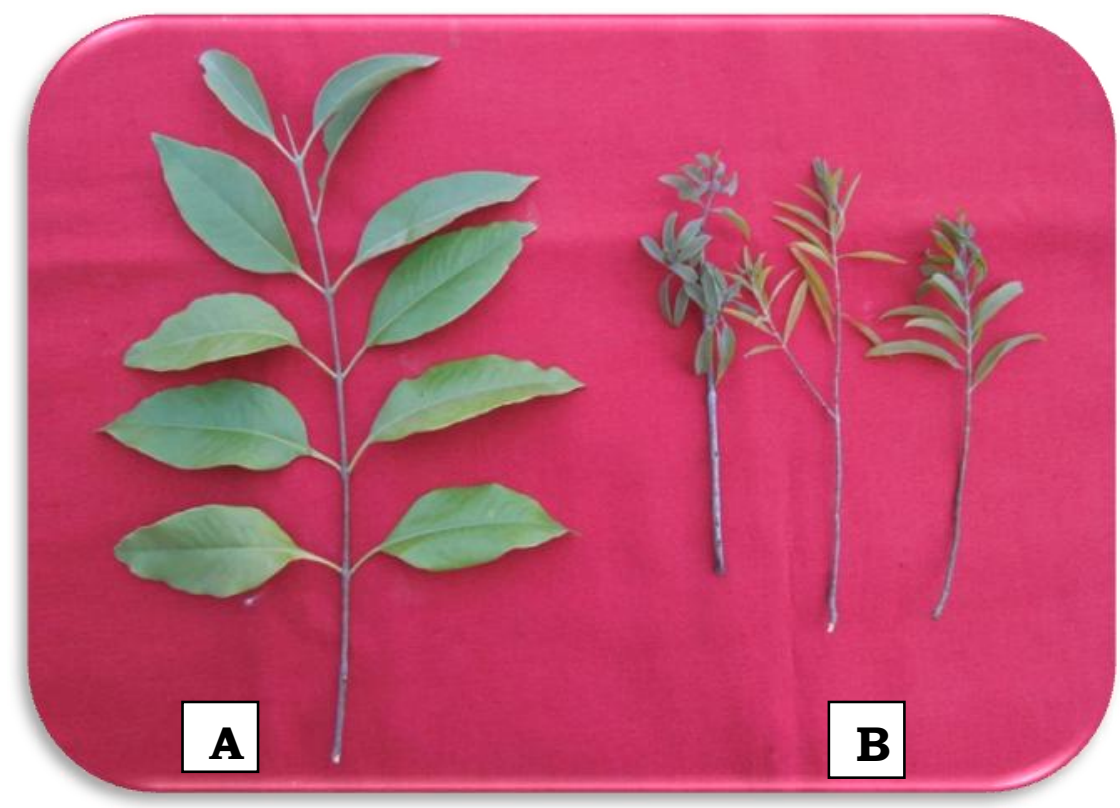

Fig.2 Close view of inflorescence of healthy (a) and phyllody infected(b) Stachytarpheta indica

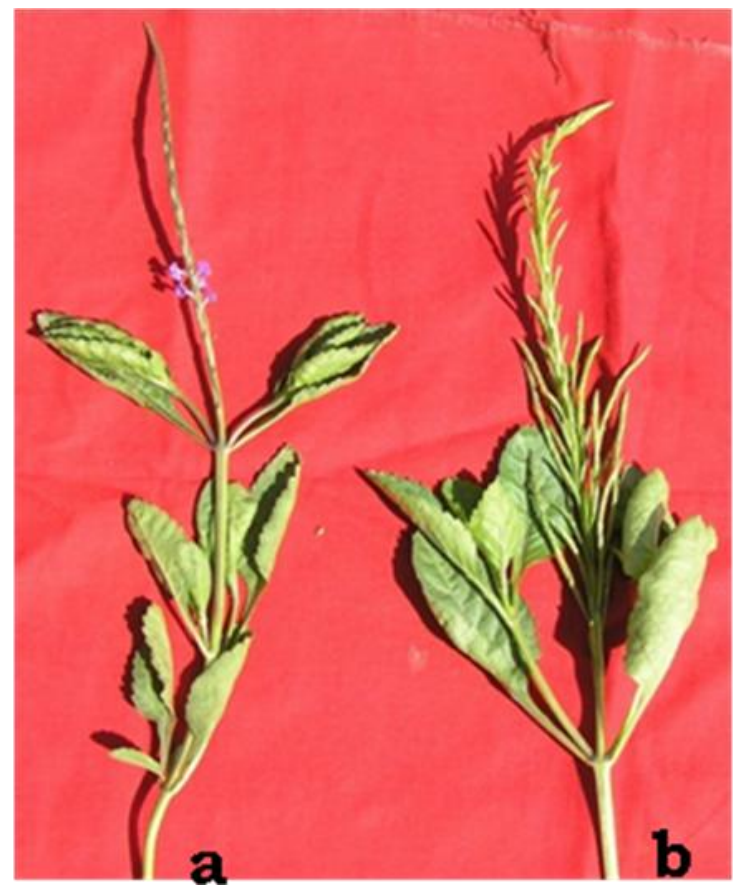


Fig.3 Experimental inoculation of spike phytoplasma to Stachytarpheta through dodder

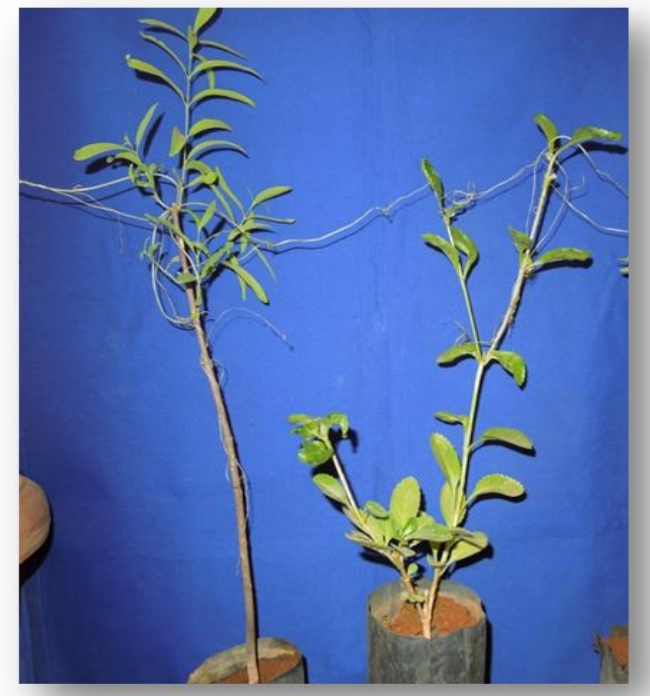

Fig.4 Detection of Sandal spike phytoplasma through PCR of infected plant samples and inoculated Stachytarpheta plants; M- 1000 bp marker; 1- Sandal spike sample;

2 \& 3- tested Stachytarpheta plants

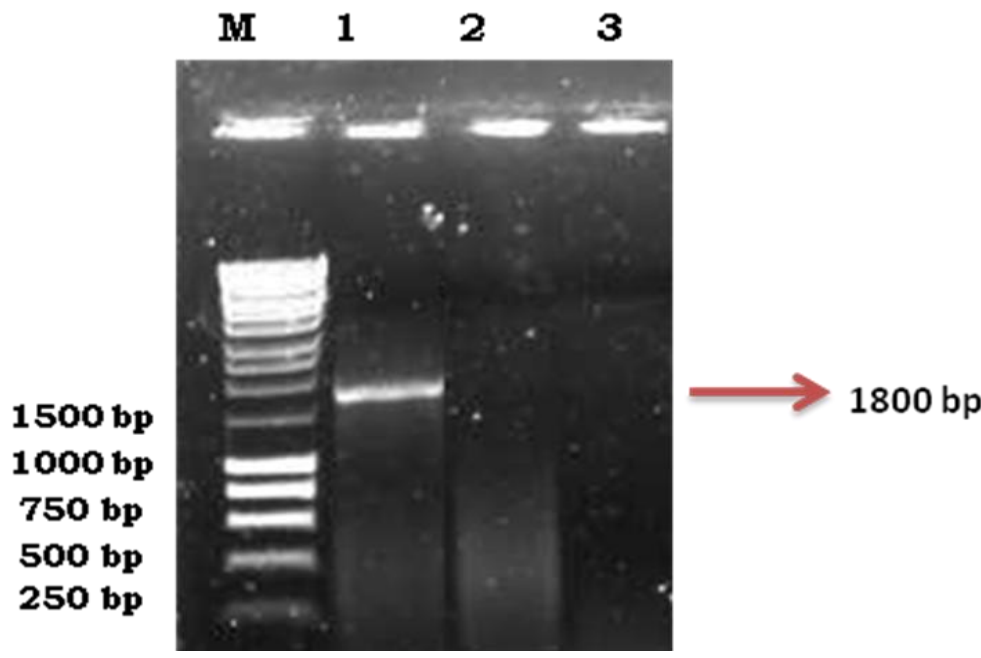

However in Shimoga district alone, the maximum incidence was 1.06 per cent in Adderi followed by 1.09 per cent in Thaligere and the minimum incidence $(0.33 \%)$ was recorded in Tyagarthi village of Sagara tuluk. Paradoxically, there was no incidence was found among five plantations in Chitrudurga, four in Chikkaballapura and five plantations in Chikkamangalore during the survey.
The cross transmission/infectivity studies were conducted to determine the role of Stachytarpheta as a host of sandal spike diseases. The healthy seedlings of Stachytarpheta were inoculated experimentally by connecting the Cuscuta dodder established on infected spike sandal plants (Fig. 3). The results revealed that spike phytoplasma could not be transmitted to any of the inoculated Stachytarpheta plants, indicating the inability of 
phytoplasma to infect and establish in the host. The PCR analysis of all dodder inoculated Stachytarpheta plants for the spike phytoplasma also gave negative results (Fig. 4). However, Venkat Rao and Gopal Iyengar (1934) reported that, the disease could be transmitted from the diseased Zizupus oenoplea and Vinca rosea to healthy Sandal plants and vice versa through dodder. Paradoxically, the hosts Sandal and Stachytarpheta are different. Hence, this study confirms that, there is no inter-relation between Sandal and Stachytarpheta for transmission of Phytoplasama.

The varied levels of disease incidence could be due to the differences in temperature, relative humidity, collateral associated within the plantations and the population of natural vectors. The disease incidence on Sandal was favoured by several factors including climatic conditions. The disease varied according to the plantations of the regions, where the climatic conditions were quite different.

However, Muniyappa et al., (1980) suggested that, the disease was mostly confined to the areas with rainfall of $800-2000 \mathrm{~mm}$, with a temperature of $24-29.5^{\circ} \mathrm{C}$ and $76-86$ per cent relative humidity. He also suggested that, these climatic factors might have playing role for vectors (Leaf and tree hoppers) multiplication and their activity, these said to be natural vectors for Phytoplasma disease.

\section{References}

Dijkstra, J and Lee, P.E., 1972, Transmission by dodder of sandal spike disease and accompanying mycoplasma like organisms via. Vinca rosea. Netherland.

\section{J. Pl. Path., 78: 218-224.}

Iyengar, A.V.V. 1969. Losses due to the Sandal spike disease and An effective method of controlling spike infection in sandal. Indian Forester., 87:563-571.

Muniyappa, V., Vijayakumar, N., SubbaRao, M. and Kushalappa, K.A., 1980, Studies on sandal spike disease in the forests of Karnataka state. Part 1, UAS, Bangalore, $284 \mathrm{pp}$.

Nayar, R. and Ananthapadmanaba, H.S., 1977, Little leaf disease in collateral hosts of sandal (Santalum album L.). European J. For. Pathol., 7: 152-158.

Rangaswamy, S. and Griffith, A.L., 1941, Demonstration of Jassus indicus (walk) as a vector of the spike disease of sandal (Santalum album L.). Indian For., 67: 387-394.

Rangaswamy, K.T., 1995, Studies on sandal spike disease. PhD. Thesis, Tamilnadu Agri. Univ. Coimbatore, 196pp.

Seliskar, C.E., Wilson,C.L., 1981, Mycoploasma diseases of trees and shrubs, pp35-94 Acadamic Press, New York. pp 35-94.

Srinivasan, V,V., Shivaramakrishnan, V.R., Rangaswamy, C.R., 1992, A monograph of Sandal spike disease published by Indian Council of Forestry Research and Education, Dehra Dun. 233.pp.

Subba Rao M., Muniyappa, V., 1980, Epidemiology of sandal spike disease. In: Tree mycoplasma disease and epidemiology, The Univ. Alborta press, pp. 57-68.

Venkat Rao, M. G., and Gopal Iyengar, K. 1934, Studies on spike disease of sandal. Indian. Forester., 60:481-491.

\section{How to cite this article:}

Murali, R., K.T. Rangaswamy and Nagaraja, H. 2019. Occurrence of Spike Disease in Sandal Plantations in Southern Karnataka and Cross Transmission Studies between Sandal Spike and Stachytarpheta phyllody through Dodder (Cuscuta subinclusa). Int.J.Curr.Microbiol.App.Sci. 8(01): 1041-1046. doi: https://doi.org/10.20546/ijcmas.2019.801.113 